\title{
The Arteries Root from the Aortic Arch in the Sparrowhawk (Accipiter nisus, Falconiformes: Accipitridae)
}

\author{
La Raíz de las Arterias desde el Arco Aórtico en el \\ Gavilán (Accipiter nisus, Falconiformes: Accipitridae)
}

\author{
Hulya Balkaya*
}

BALKAYA, H. The arteries root from the aortic arch in the sparrowhawk (Accipiter nisus, Falconiformes: Accipitridae). Int. J. Morphol., 34(1):110-115, 2016.

SUMMARY: This study was aimed at determining the morphology of the aortic arch in the sparrowhawk. For this purpose, arteries near the heart of six sparrowhawks were assessed. Latex injection method was applied to the three materials and barium sulphate solution was injected into the aorta for angiography in three other materials. It was observed that two major arteries arose from aortic arch in the sparrowhawk: the left brachiocephalic trunk and the right brachiocephalic trunk. These trunks were contiguous arteries but separately originated from the aorta. The brachiocephalic trunks were divided into the common carotid and subclavian arteries after their origins. First, the common carotid arteries are given off by the brachiocephalic trunks. The common carotid artery was giving off esophagotracheobronchial artery and vertebral trunk. Vertebral trunk was locating under the brachial plexus. The subclavian artery was continuations of the brachiocephalic trunk and it was bifurcating to the axillar artery and the pectoral trunk just from its own beginning. The axillary artery passed the brachial plexus crosswise from above, and reached to the wing. The sternoclavicular artery stemmed from ventral aspect of the begining of the axillary artery. The thickest branch of the subclavian artery was the pectoral trunk, which was branched the cranial external thoracic artery, the caudal external thoracic artery, the dorsal thoracic artery, and the internal thoracic artery. It is hoped that the results of this morphological study will contribute to the species specific anatomical data in the birds.

KEY WORDS: Sparrowhawk; Accipiter nisus; Aortic arch; Brachiocephalic trunk.

\section{INTRODUCTION}

In birds, as in mammals, there are two types of blood circulation, small (pulmonary) circulation, which carries venous blood and large (systemic) circulation whose main vessel, the aorta, carries arterial blood. The aorta arises from the left ventricle. Bending to the right it forms the aortic arch (Nickel et al., 1977). The arteries that carry blood to the head, neck, forelimbs and cranial section of the thoracic cavity originate from the aortic arch. In ruminants and equines, one major vessel root from aortic arch, brachiocephalic trunk (Schummer et al., 1981; Dursun, 1995). However, in pig, dog, cat, rabbit and guinea-pig, two major vessels root from aortic arch: brachiocephalic trunk and left subclavian artery (Schummer et al.; Dursun; Shively \& Stump, 1974; Mclaughlin \& Chiasson, 1990; Tipirdamaz et al., 1998; Kabak \& Haziroglu, 2003). In contrast to mammals, in birds, two brachiocephalic trunks root mainly from the aortic arch: the left brachiocephalic trunk and the right brachiocephalic trunk. Both right and left brachiocephalic trunks emerge from left side of the aortic arch and give rise to the common carotid and subclavian arteries (Nickel et al.; Baumel et al., 1993).

Some researches have been conducted to define the root from the aortic arch in different mammals, for example, ruminants (Lee \& Lee, 1984; Ahn et al., 2008), rodents (Atalar et al., 2003; Aydin, 2011) and carnivores (Rochat \& Settles, 1993; Ferrigno et al., 2001; Kim et al., 2006). The number of researches about species specific arterial structure, in avian species is remarkably fewer than those carried out in mammals and the number of species specific literatures with regard to the arterial structure of the aortic arch in recent years are restricted (Erdogan, 2012; Erdogan \& Kilinc, 2014). 
Quail hunting with sparrowhawks is a traditional sport in Anatolia. This method is commonly used for quail hunting in northeastern Turkey. The sparrowhawk is a small bird of prey from the family Accipitridae. Throughout the world there are 50 different species of the genus Accipiter. It is a major predator of small birds, especially sparrows (Baris, 2004). Despite its importance in Turkey, there isn't any information about the anatomy of the vascular system in the sparrowhawk. This opportunity encouraged us to study the anatomy of the the arterial architecture of the aortic arch in the hope that our described findings will boost the understanding of vascular structure in wild birds.

\section{MATERIAL AND METHOD}

In this study, a total of six wounded and clinically incurable sparrowhawks that provided by certified hunters during the hawk migration season in the Ardesen town of Rize and brought to the clinic (Faculty of Veterinary Medicine, Ataturk University) were used. Their weights ranged from 150 to $250 \mathrm{~g}$ and sex differences were not considered. First, $5 \mathrm{mg} / \mathrm{kg}$ of xylazine, followed by $30 \mathrm{mg} / \mathrm{kg}$ of ketalar, were injected into the muscles of all the birds for anesthesia (Belge \& Bakir, 1999; Flecknell, 1992). Under deep anaesthesia, blood was drained by cutting off the apex of the heart and the vessels were cleaned out by administering $0.9 \%$ of physiologic saline water into the vessels. Latex colored with dye was injected into the left ventricle of the heart through aorta at three materials (Hassa, 1967). After keeping in tap water at room temperature for $24 \mathrm{~h}$, the region of the heart of the cadavers were thoroughly dissected and revealed aortic arch and its branches were photographed.

Forty-five $\mathrm{kW}$ doses of barium sulphate solution were injected into the aorta for angiography in three materials. Angiographies were taken at ventrodorsal position. One hundred kW 30 mAS Poskom brand x-ray were used for angiography.

The terminology used in this study is compatible with that of the Nomina Anatomica Avium (Baumel et al., 1993).

\section{RESULTS}

Two major arteries branched off from aortic arch in the sparrowhawk: the left brachiocephalic trunk and the right brachiocephalic trunk. It was seen that these trunks were contiguous arteries but separately originated from the aorta. In the present study, it was detected that the first branch that ramified from the aortic arch was the left brachiocephalic trunk and the second branch was the right brachiocephalic trunk. After this ramification, the arch of the aorta displayed a craniodorsal curvature. The bifurcation of the left brachiocephalic trunk and the right brachiocephalic trunk was locating caudoventral to the syrinx and partially cranioventral to the principal bronchus. It was observed that the brachiocephalic trunks were divided into common carotid and subclavian arteries in their course after their origins from aorta. The common carotid arteries were thinner than subclavian arteries and they ran cranially. The subclavian arteries were continuations of the brachiocephalic trunks and they were proceeding in both of the lateral sides of the body as short and thick vessels (Figs. 1 and 2).

First, the common carotid arteries are given off by the brachiocephalic trunks, and after that, the trunks branch the subclavian and axilary arteries. The common carotid arteries that spread from the anterior aspect of the brachiocephalic trunks were bending craniomedially and running on both lateral sides of the neck. During this course, it was observed that the common carotid artery was initially giving off esophagotracheobronchial artery from its medial aspect and then the vertebral trunk from its lateral aspect. The esophagotracheobronchial artery was generally an arterial trunk in appearance that included complex of arteries. These complex arteries were supplying to caudal of the trachea, syrinx, principal bronchus, esophagus, and thyroid gland. The vertebral trunk, which was arising from lateral aspect of common carotid artery, was carrying blood to axial muscles, vertebral column, and cervical muscles. This trunk was locating under the brachial plexus (Fig. 1).

The subclavian artery that was the continuation of brachiocephalic trunk was bifurcating to the axillar artery and the pectoral trunk just from its own beginning. It was seen that the axillary artery passed the brachial plexus crosswise from above, and reached to the wing (Figs. 1 and 2). The sternoclavicular artery stemmed from ventral aspect of the begining of the axillary artery and it was a fairly thin branch. This artery was ramifying a sternal and a clavicular artery supplying entrance of the cranial thoracic aperture and pectoral muscles (Fig. 1). After the ramifying of the sternoclavicular artery, the axillary artery carrying blood to the wing was originating from the subclavian artery and was then coursing deep into the shoulder (Figs. 1 and 2). The thickest branch of the subclavian artery was the pectoral trunk, which was branched the cranial external thoracic artery, the caudal external thoracic artery, the dorsal thoracic artery, and the internal thoracic artery. These branches were running into the deep pectoral muscles, dorsal thoracic region, the internal wall of the thorax, superficial pectoral muscle and the feather follicles and skin over the caudodorsal of the thoracic region (Figs. 1 and 2). 


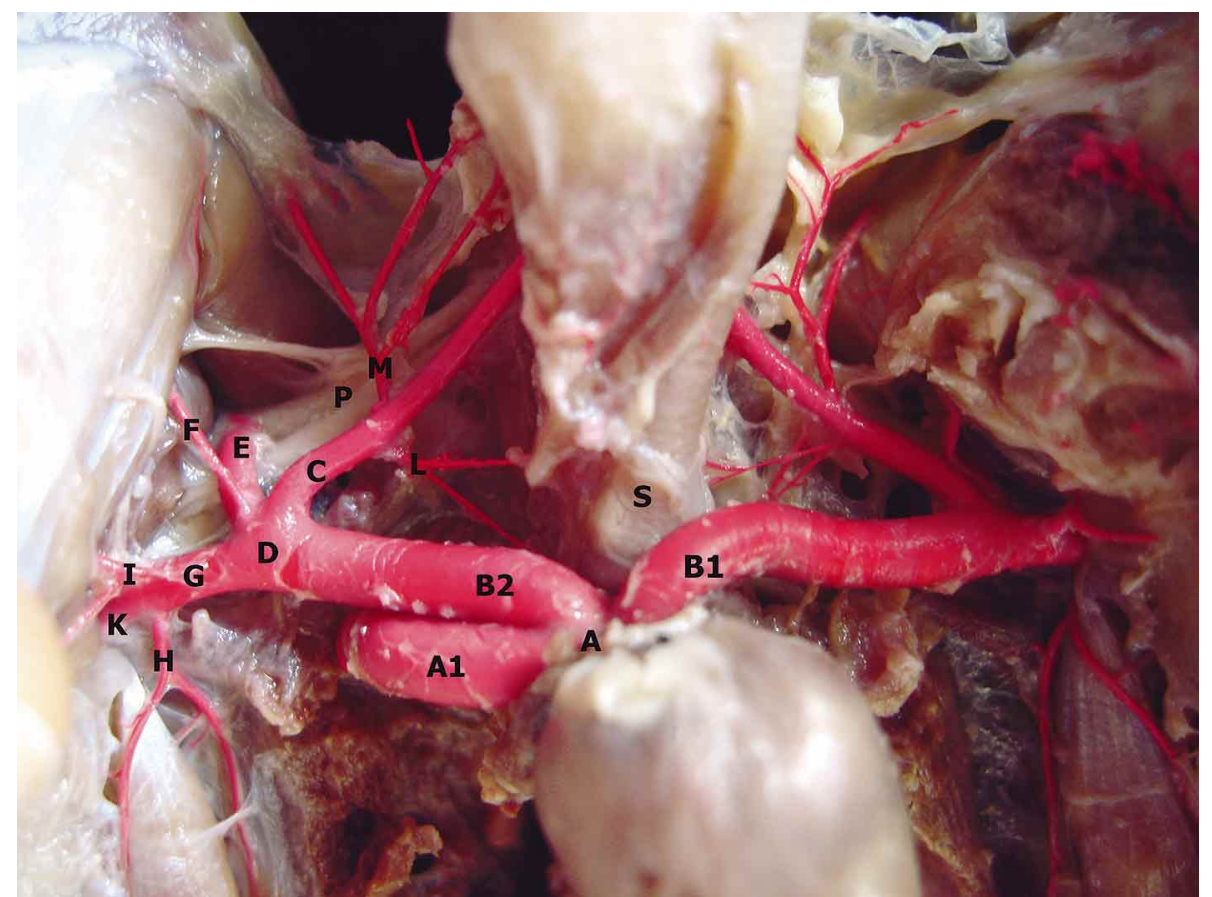

Fig. 1. Arteries root from aortic arch in sparrowhwk as visualized by latex injection method in ventral view. A. Aortich arch, A1. Aorta, B1. Left brachiocephalic trunk, B2. Right brachiocephalic trunk, C. Common carotid artery, D. Subclavian artery, E. Axillary artery, F. Sternoclavicular artery, G. Pectoral trunk, H. Internal thoracic artery, I. Cranial external thoracic artery, K. Caudal external thoracic artery, L. esophagotracheobronchial artery, M. Vertebral trunk, P. Brachial plexus, S. Syrinx.

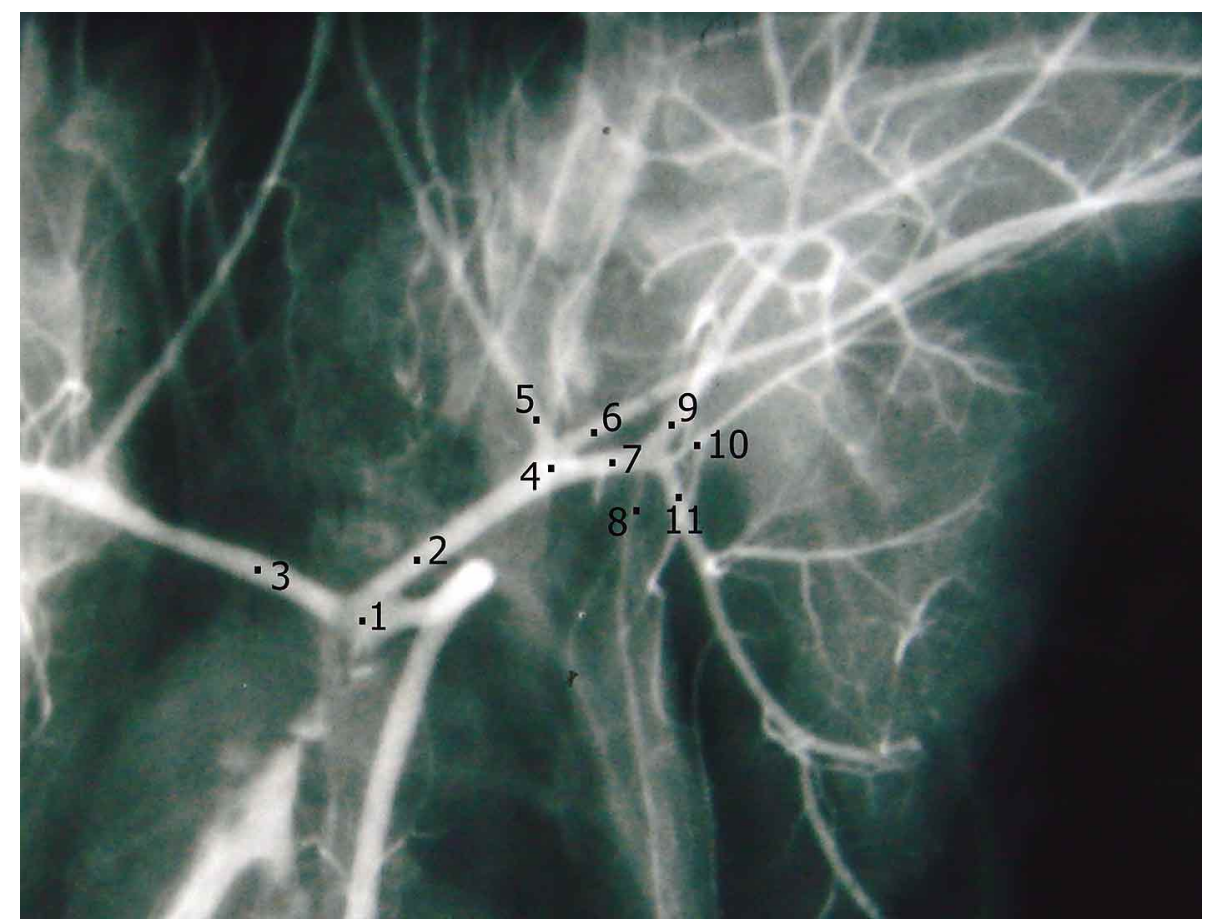

Fig. 2. Images of angiography of aortic arch and its branches in sparrowhawk. 1. Aortich arch, 2. Right brachiocephalic trunk, 3. Left brachiocephalic trunk, 4. Subclavian artery, 5. Common carotid artery, 6. Axillary artery, 7. Pectoral trunk, 8. Internal thoracic artery, 9. Cranial external thoracic artery, 10. Dorsal thoracic artery, 11. Caudal external thoracic artery. 


\section{DISCUSSION}

Bending to the right, the ascending aorta forms the aortic arch and gives off first the left brachiocephalic artery and immediately afterwards the right brachiocephalic artery in domestic birds. The head, neck, wing and pectoral regions are supplied by brachiocephalic arteries. These arteries arise from the aorta at the base of the heart before the aortic arch bends to the right in its craniodorsal convex curve (Nickel et al.). Likewise, we determined that the aortic arch gave off first the left brachiocephalic trunk and immediately afterwards the right brachiocephalic trunk in the sparrowhawk. Similarly, in the sparrowhawk we observed that arch of the aorta displayed a craniodorsal curvature and blood was carried to head, neck, wing and pectoral regions by the brachiocephalic trunks. Similar to the reports of Erdogan and Erdogan \& Kilinc, in the Eurasian bittern and long-legged buzzard, we observed that the brachiocephalic trunks were contiguous arteries but separately originated from the aorta in the sparrowhawk. We determined the same ramification type and nearly equal lengths on the left and right brachiocephalic trunks of the examined cadavers. This appearance was observed in both the latex-injected cadavers and the angiographic images of cadavers. Unlike our findings, it was reported that the left trunk was longer than the right one in the long-legged buzzard (Erdogan \& Kilinc).

In the sparrowhawks examined in this study, each brachiocephalic trunk was divided into the common carotid and subclavian arteries as reported by Nickel et al. in the domestic birds, by Baumel et al. in the birds, by Erdogan in the Eurasian bittern and by Erdogan \& Kilinc, in the longlegged buzzard. Similar to the report of Baumel et al., we observed that the common carotid artery was giving off the esophagotracheobronchial artery from its medial aspect and then the vertebral trunk from its lateral aspect. Glenny (1955) named the esophagotracheobronchial artery as the ductus shawi and Bhaduri et al. (1957) defined this artery as the syringotracheobronchial artery. The general distribution of the esophagotracheobronchial artery is to the caudal trachea and syrinx, principal bronchus, pericardium, esophagus, thyroid, parathyroid and ultimobronchial glands (Baumel et $a l$.). Similarly, it was reported that the common carotid artery branched to the thyroid artery, tracheosyringeal artery, and esophageal branches in the Eurasian bittern (Erdogan) and the tracheosyringeal branch or syringo tracheobronchial artery were distributed in the caudal part of the trachea and its bifurcation (syrinx) and main bronchi in the long-legged buzzard (Erdogan \& Kilinc). A similar vessel distribution of the common carotid and esophagotracheobronchial artery were also detected here in the sparrowhawk. However, the bronchoesophageal artery ramified from the subclavian artery just lateral to the origin of the common carotid artery in the coturnix quail (Fitzgerald, 1969). Thyroid gland was supplied by three thyroid arteries, cranial, middle, and caudal in the budgerigar and caudal thyroid arteries in most cases were the branch or the branches of the respective oesophagotracheobronchial artery (Radek \& Piasecki, 2004). In the present study, we observed that thyroid gland was generally supplying by artery ramified from the oesophagotracheobronchial artery in the sparrowhawk. In our study, the common carotid artery gave off the vertebral trunk in the sparrowhawk as in the long-legged buzzard (Erdogan \& Kilinc), the Eurasian bittern (Erdogan) and some bird families such as Coliiformes (Glenny, 1944), Gaviiformes (Glenny, 1945), Charadriiformes (Glenny, 1947), Caprimulgiformes (Glenny, 1953a) and Ciconiiformes (Glenny, 1953b).

In the present study, the subclavian artery was the continuation of the brachiocephalic trunk laterally to the thoracic wall and it gave rise to the pectoral trunk and the sternoclavicular (coracoid) artery before becoming the axillary artery as reported in the coturnix quail (Fitzgerald). However, acromial artery which proceeded to the shoulder joint was not branching from the subclavian artery as reported by Nickel et al. in domestic birds was mentioned. It was shown that in coturnix quail and Eurasian bittern the sternoclavicular or coracoid artery arose on the ventral surface of the subclavian artery between the pectoral trunk (external thoracic artery) and axillary artery (Erdogan; Fitzgerald). However, the sternoclavicular artery was absent in birds belonging to the Fringillidae (Glenny, 1942) and Trogoniformes (Glenny, 1943).

It was reported that in domestic birds, the axillary artery was an independent branch of the subclavian artery and not as in mammals, the continuation of that vessel (Nickel et al.). Likewise, we observed that in the sparrowhawk, the axillary artery was ramifying from the subclavian artery as reported in the Eurasian bittern (Erdogan). However, Fitzgerald designated that the axillary artery was the continuation of the subclavian artery in the coturnix quail. The pectoral trunk was also named as the external thoracic artery by Baumel et al. in birds. The pectoral trunk was the thickest branch of the subclavian artery and the cranial external, caudal external, dorsal and internal thoracic arteries originated from this trunk in the present study. Fitzgerald reported the same findings for the coturnix quail. Similar to the domestic birds (Nickel et al.), we observed that the external thoracic artery was giving rise to a conspicuous dorsal and ventral ramus: cranial and caudal external thoracic artery. In addition, the internal thoracic artery divided into dorsal and ventral branches in the sparrowhawk. However, the lateral thoracic artery was absent in our study. 
BALKAYA, H. The arteries root from the aortic arch in the sparrowhawk (Accipiter nisus, Falconiformes: Accipitridae). Int. J. Morphol., 34(1):110-115, 2016.

In conclusion, in the present study, the vascular arrangement and branches of the aortic arch in the sparrowhawk were determined using both latex-injected material and the angiographic images. This study was the first description of the macroanatomical research of the aortic arch in the sparrowhawk. The results of the present study will shed light on researches regarding vascular organization in the region of the heart in birds of prey. In addition, these results will contribute to comprehension of species spesific macro anatomical data among bird species.

Ethics statement. All procedures were carried out in exact accordance with the principles of Ataturk University Local Ethical Committee of Animal Experiments.

BALKAYA, H. La raíz de las arterias desde el arco aórtico en el gavilán (Accipiter nisus, Falconiformes: Accipitridae). Int. J. Morphol., 34(1):110-115, 2016.

RESUMEN: El objetivo fue determinar la morfología del arco aórtico en el gavilán. Para este fin, se evaluaron las arterias próximas al corazón de seis gavilanes. En tres aves se inyectó una solución de látex, mientras que en las tres restantes se inyectó a través de la aorta sulfato de bario para someterlas luego a un estudio por angiografía. Se observó el origen de dos arterias principales del arco aórtico del gavilán: el tronco braquiocefálico izquierdo y el tronco braquiocefálico derecho. Estos troncos se presentaron como arterias contiguas, pero que se originaron por separado de la aorta. Los troncos supraaórticos se dividieron después de su origen en las arterias carótida común y subclavia. Las arterias carótidas comunes se emiten a partir de los troncos supraaórticos. La arteria carótida común emitió una arteria esófagotraqueobronquial y el tronco vertebral. El tronco vertebral se localizó por debajo del plexo braquial. La arteria subclavia se continuó a partir del tronco braquiocefálico y se bifurcó en arteria axilar y tronco de las arterias pectorales justo desde su propio inicio. La arteria axilar cruzó el plexo braquial transversalmente desde arriba, y llegó al ala. La arteria esternoclavicular derivó de la cara ventral del inicio de la arteria axilar. La rama más gruesa de la arteria subclavia fue el tronco de las arterias pectorales, que se ramificó en arteria torácica externa craneal, arteria torácica externa caudal, arteria torácica dorsal, y la arteria torácica interna. Se espera que los resultados de este estudio morfológico sean una contribución para aportar datos anatómicos específicos en esta especie de aves.

PALABRAS CLAVE: Gavilán; Accipiter nisus; Arco aórtico; Tronco braquiocefálico.

\section{REFERENCES}

Ahn, D. C.; Kim, H. C.; Tae, H. J.; Kang, H. S.; Kim, N. S.; Park, S. Y. \& Kim, I. S. Branching pattern of aortic arch in the Korean water deer. J. Vet. Med. Sci., 70(10):1051-5, 2008.
Atalar, O.; Yilmaz, S.; Burma, O. \& Ilkay, E. The macroanatomical investigations on the aortic arch in porcupines (Hystrix cristata). Anat. Histol. Embryol., 32(6):367-9, 2003.

Aydin, A. The arteries originating from the aortic arch and the branches of these arteries in red squirrels (Sciurus vulgaris). Vet. Med. Czech., 56(3):131-4, 2011.

Baris, S. Geleneksel Atmacacilik, Cevre ve Orman Bakanligi, Doga Koruma ve Milli Parklar Genel Mudurlugu. Ankara, Nurol Matbaacilik, 2004. pp.19-28.

Baumel, J. J.; King, S. A.; Breazile, J. E.; Evans, H. E. \& Vanden Berge, J. C. Handbook of Avian Anatomy. Nomina Anatomica Avium. $2^{\text {nd }}$ ed. Cambridge, Nuttall Ornithological Club, 1993. pp. 469-81.

Belge, A. \& Bakır, B. Veteriner Anestezioloji ve Reanimasyon (Ders notlarl). Van, Yüzüncü Y1l Üniversitesi Veteriner Fakültesi Yayınları, 1999.

Bhaduri, J. L.; Biswas, B. \& Das, S. K. The arterial system of the domestic pigeon (Columba livia Gmelin). Anat. Anz., 104(15):1-14, 1957.

Dursun, N. Veteriner Anatomi II. Systema vasorum angiologia. Ankara, Medisan Yayiveni, 1995. pp.211-29.

Erdogan, S. \& K1lınc, M. The branching pattern of the aortic arch in the long-legged buzzard (Buteo rufinus Cretzschmar 1829). Anat. Sci. Int., 89(3):151-5, 2014.

Erdogan, S. The branching of the aortic arch in the Eurasian bittern (Botaurus stellaris, Linnaeus 1758). Vet. Med. Czech., 57(5):239-44, 2012.

Ferrigno, C. R.; Ribeiro, A. A.; Rahal, S. C.; Orsi, A. M.; Fioreto, E. T.; Castro, M. F.; Mchado, M. R. \& Singaretti, F. Double aortic arch in a dog (Canis familiaris): a case report. Anat. Histol. Embryol., 30(6):379-81, 2001.

Fitzgerald, T. C. The Coturnix Quail. Anatomy and Histology. Ames, Iowa State University Press, Iowa, 1969. pp.69-76.

Flecknell, P. A. Laboratory Animal Anaesthesia: An Introduction for Research Workers and Technicians. London, Academic Press, 1987.

Glenny, F. H. A systematic study of the main arteries in the region of the heart--aves III: The Fringillidae. Part 1. Ohio J. Sci., 42(2):84-90, 1942.

Glenny, F. H. A Systematic study of the main arteries in the region of the heart--aves VI. Trogoniformes, Part 1. The Auk, 60(2):235-9, 1943

Glenny, F. H. A systematic study of the main arteries in the region of the heart--aves IX: Coliiformes. Part 1. Ohio J. Sci., 44(6):273-6, 1944 
Glenny, F. H. A systematic study of the main arteries in the region of the heart--aves XV: Gaviiformes. Part 1. Ohio J. Sci., 45(4):167-9, 1945.

Glenny, F. H. A systematic study of the main arteries in the region of the heart--aves XVI: Charadriiformes. Part 1. Ohio J. Sci., 47(4):152-4, 1947.

Glenny, F. H. A systematic study of the main arteries in the region of the heart aves XX: Caprimulgiformes, Part 1. Ohio J. Sci., 53(6):356-7, 1953a.

Glenny, F. H. A systematic study of the main arteries in the region of the heart. Aves XIII: Ciconiiformes, Part 2. Ohio J. Sci., 53(6):347-8, 1953b.

Glenny, F. H. Modifications of pattern in the aortic arch system of birds and their phylogenetic significance. Washington D. C., Proc. U. S. Nat. Mus. 104, 1955. pp.525-621.

Hassa, O. Koroner damarların plastik demostrasyonu için pratik enjeksiyon metodu. Ankara Üniv. Vet. Fak. Derg., 14:444-53, 1967.

Kabak, M. \& Haziroglu, R. M. Subgross investigation of vessels originating from arcus aortae in guinea-pig (Cavia porcellus). Anat. Histol. Embryol., 32(6):362-6, 2003.

Kim, N. S.; Alam, M. R. \& Choi, I. H. Persistent right aortic arch and aberrant left subclavian artery in a dog: a case report. Vet. Med. Czech., 51(4):156-60, 2006.

Lee, H. S. \& Lee, J. S. Anatomical studies on patterns of branches of aortic arch in Korean native goat. Korean J. Vet. Res., 24(1):17, 1984.

McLaughlin, C. A. \& Chiasson, R. B. Laboratory Anatomy of the Rabbit. $3^{\text {rd }}$ ed. New York, McGraw-Hill, 1990. pp.67-71.

Nickel, R.; Schummer, A. \& Seiferle, E. Anatomy of the Domestic Birds. Berlin, Verlag Paul Parey, 1977. pp.87-99.

Radek, T. \& Piasecki, T. The topographical anatomy and arterial supply of the thyroid and parathyroid glands in the budgerigar (Melopsittacus undulatus). Folia Morphol. (Warsz), 63(2):16371, 2004.

Rochat, M. C. \& Settles, E. Persistent right aortic arch in a cougar (Felis concolor). J. Zoo Wildl. Med., 24(4):534-8, 1993.

Schummer, A.; Wilkens, H.; Vollmerhaus, B. \& Habermehl, K. H. The Circulatory System, the Skin, and the Cutaneous Organs of the Domestic Mammals. In: Nickel, R.; Schummer, A. \& Seiferle, E. (Eds.). The Anatomy of the Domestic Animals. Vol. 3. Berlin, Verlag Paul Parey, 1981. pp.72-7.

Shively, M. J. \& Stump, J. E. The systemic arterial pattern of the guinea pig: the head, thorax, and thoracic limb. Am. J. Anat., 139(2):269-84, 1974.
Tıpırdamaz, S.; Yalçın, H. \& Dursun, N. Macroanatomical investigations on the branches of the aortic arch in Kangal dogs. Turk. J. Vet. Anim. Sci., 14:87-90, 1998.

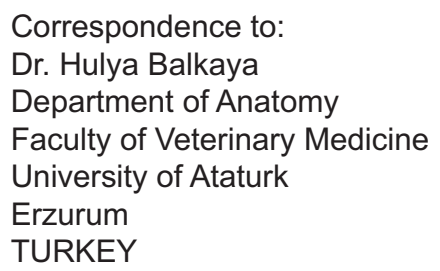

Tel: +90-442-2315532

Email: balkayaibrahim@hotmail.com

Received: 08-07-2015

Accepted: 18-11-2015 